\title{
Muito Além da Alma do Negócio - Análise dos Recursos de Apropriação do Outro pelo Fetiche da Mercadoria na Propaganda ${ }^{1}$
}

\author{
Vinícius de Oliveira Bessi ${ }^{2}$
}

\section{Resumo}

Esta pesquisa tem como proposta a análise de três peças publicitárias que foram premiadas na sexagésima edição do Festival Leões de Cannes do ano de 2013. A análise tem como objetivo identificar quais os recursos comunicacionais, linguísticos, estéticos, simbólicos e de apelo psíquico utilizados pelas propagandas para manejar a diversidade sociocultural (que foi conduzida historicamente à necessidade compulsória dos contatos institucionalizados entre suas localidades pela expansão geográfica e comunicacional do capitalismo na globalização) como ideologia aparente e superestrutural do fetichismo da mercadoria.

O Festival Leões de Cannes é um concurso mundial de publicações do segmento publicitário, criado no ano de 1954 pela Screen Advertising Worlds Agencies (SAWA) e realizado anualmente na cidade da Riviera Francesa que lhe dá nome, sendo criado para estabelecer padrões internacionais de qualidade para a produção do mercado publicitário audiovisual. SAWA julgava somente a categoria de filmes publicitários e nenhum outro tipo de propaganda até 1991, mas atualmente são 13 categorias premiadas por Cannes:

\footnotetext{
1 Proposta de iniciação científica e monografia desenvolvida com a orientação da professora doutora Marina Soler da Escola de Filosofia, Letras e Ciências Humanas da Universidade Federal de São Paulo.

2 zaifonvias@gmail.com / 11 97227-5697. Universidade Federal de São Paulo; Escola de Filosofia, Letras e Ciências Humanas; Curso de Ciências Sociais
} 
- Branded Content \& Entertainment - Posicionamento de marca no segmento;

- Creative Effectiveness - Campanhas de melhor retorno às metas do cliente;

- Cyber - Propagandas e peças publicitárias de internet;

- Design - Projetos de desenho industrial e programação visual;

- $\quad$ Direct - Marketing direto;

- Film - Filme publicitário de melhor conteúdo;

- Film Craft - Filme publicitário de melhor produção;

- Innovation (*) - Inovação tecnológica para o impulso criativo;

- Media - Plano de mídia;

- Mobile - Propagandas e peças publicitárias para celular, smartphone e tablet;

- Outdoor - Propagandas e peças publicitárias para ambientes externos;

- $\quad$ PR - Relações públicas;

- Titanium Integrated - Ideia criativa e sua integração em diversas mídias.

Os prêmios (em ordem crescente de importância) de cada categoria são: Bronze, Prata, Ouro e Grand Prix. A avaliação é feita por um júri de publicitários dos países de maior participação e cada júri possui um chefe de júri composto pelos CEOs do festival.

Na edição 2013 foram inscritos 35.765 projetos de 92 países, aumento de $4 \%$ em relação ao número dos projetos inscritos de 2012. Apenas o Brasil concorreu com 3.476 projetos (crescimento de 1,7\% comparado a 2012), sendo o segundo maior participante, apenas atrás dos Estados Unidos que fizeram 6.078 inscrições. Reino Unido com 2.671, Alemanha com 1.994, França (1.454), Austrália (1.404), Índia (1.110), Canadá (1.106) e Japão (1.093) completam a lista dos principais participantes. 
As peças publicitárias escolhidas para a análise pertencem às campanhas:

\section{DUMB WAYS TO DIE - www.dumbwaystodie.com}

Campanha de conscientização sobre os procedimentos básicos de segurança que a população deve ter quando estiver no metrô de Melbourne. Um filme publicitário com jingle, que ilustra ludicamente, desde acidentes recorrentes em situações cotidianas, por causa da falta de atenção nos afazeres diários, até mortes em situações absurdas também por falta de uma atenção básica naquilo que se está fazendo. A propaganda se tornou um viral em diversos países, obtendo milhões de visualizações, apesar de ser uma campanha local. A peça publicitária foi criada pela agência McCann Erickson de Melbourne para o cliente Metro Trains e premiada nas categorias Integrated, Film, Direct, PR e Radio.

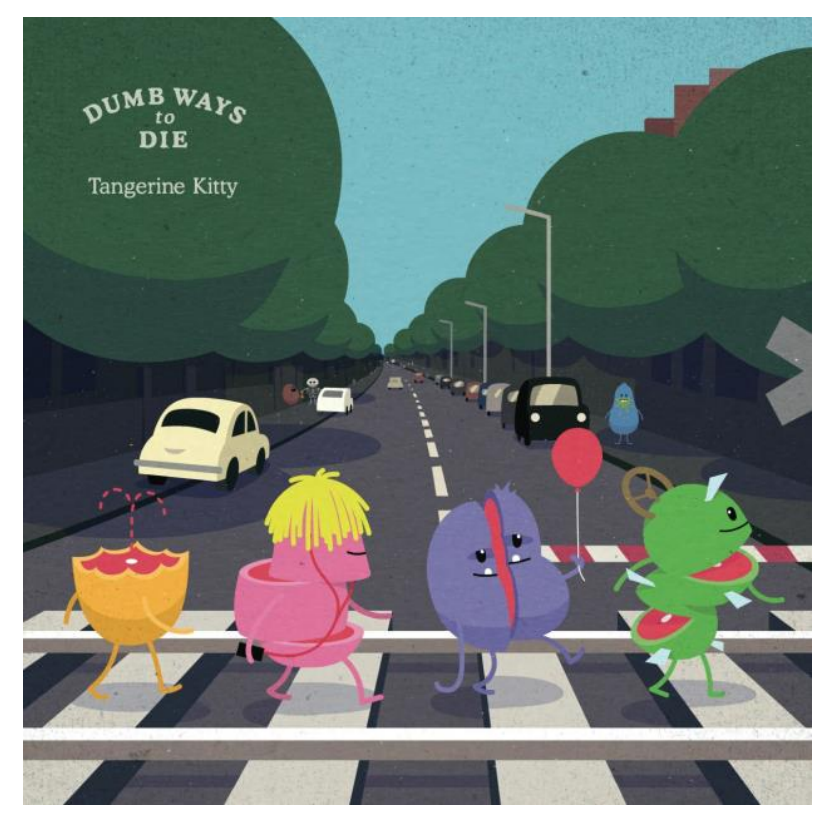




\section{TXTBKS - www.seeourentry.com/txtbks}

Campanha para fornecimento de conteúdo didático por meio de mensagens SMS para celulares analógicos, como opção aos livros didáticos para as crianças filipinas que cursam a educação básica e sofrem com a falta de infraestrutura e recursos para comprar aparelhos digitais. A propaganda é a própria mercadoria, o próprio chip que contém nas mensagens SMS o conteúdo didático. A mercadoria-propaganda foi criada pela agência DM9 de Filipinas para o cliente Smart Communications. A campanha foi premiada pela categoria Mobile de Cannes.

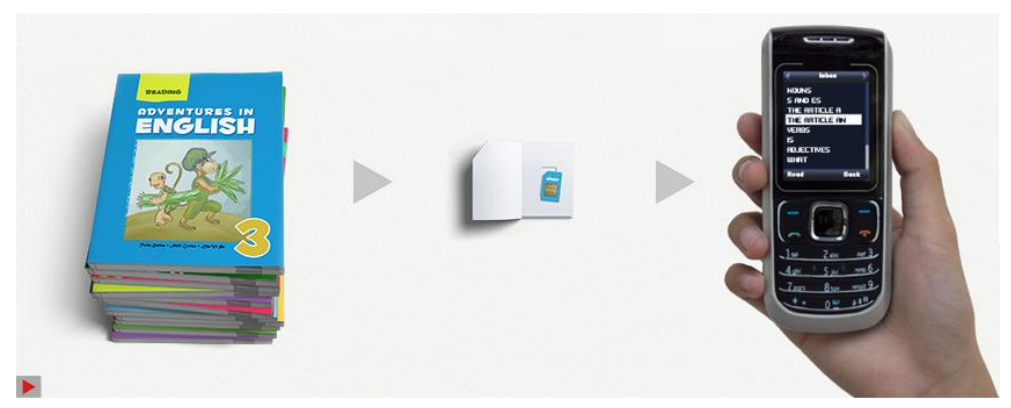

\section{RETRATOS DA REAL BELEZA - www.dove.com.br/Dove-Retratos- da-R}

Campanha institucional para a marca de produtos de higiene pessoal, cosméticos e beleza Dove que busca desconstruir certos padrões idealizados de beleza, incentivando o aumento da autoestima das mulheres com relação à própria aparência. A propaganda é um filme publicitário viral de internet que mostra um ilustrador fazendo retratos falados de mulheres que se autodescreviam e de terceiras que também as descreviam, os retratos das últimas saíam muito melhor do que os retratos de autodescrição, indicando que para outras mulheres a mulher em

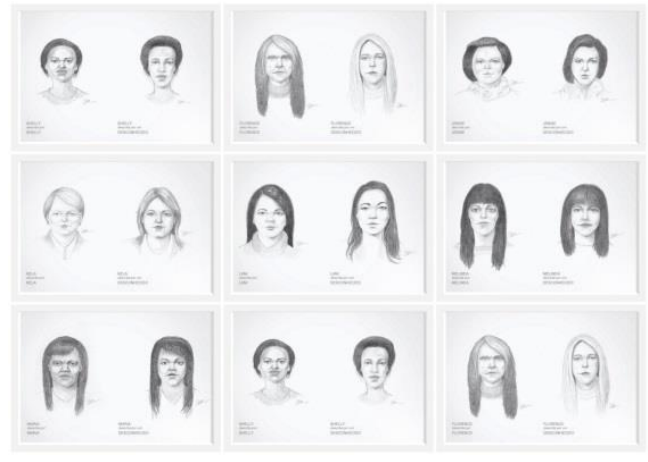


específico é muito mais bela do que ela própria se vê. Esta propaganda foi criada pela agência Ogilvy \& Mather Brasil para o cliente Unilever e foi premiada em Cannes pela categoria Titanium.

Percebe-se pela dimensão do festival, a aderência que a propaganda tem galgado com o passar dos anos nas diversas localidades do globo. São 92 países participantes na edição 2013, denotando o tom de diversidade que a propaganda possa estar trabalhando. Uma espécie de ritual de passagem da diversidade sociocultural precedente ao encontro com o capitalismo para o fetiche da mercadoria, almejando a legitimidade de habitus da prática profissional dos agentes destes dois campos sociais a nível mundial.

Com o acontecimento da Globalização, realizado pelos instrumentos técnicos do capitalismo, meios de comunicação/informação e as suas redes, as diferentes localidades do globo passaram a estabelecer encontros recorrentes e imanentes as suas necessidades. Em decorrência de tal evento, os fenômenos de estranhamento e transformação (dos que se encontraram), pautados pelas relações de poder, se tornam enfim, institucionalizados. Acaba por ser o capitalismo a estrutura social, pela qual, os encontros entre as estruturas locais se estabelecem. Contudo, o capitalismo, após cada encontro institucionalizado na Globalização, deixa de ser o mesmo de onde fora criado (sociedades ocidentais europeia e norte americana dos séculos XVIII ao XX) ao passo que também a própria diversidade sociocultural local se diferencia ao seu precedente dos encontros com o capitalismo.

O capitalismo tende costurar sua estrutura de relações das contradições dialéticas da luta de classes entre a burguesia e o proletariado (que se manifestam com as divisões técnica e social do trabalho como material e imaterial na extorsão de mais-valia absoluta ou relativa, no 
processo de produção como soma de processos de trabalho e valorização das subsunções formal ou real do trabalho, veladas numa superestrutura de ordenamento jurídico pela burocracia de aparelho político dos Estados Nacionais) com a diversidade das estruturas socioculturais das demais localidades onde ocorrem os seus encontros.

Tendo nos condicionamentos emocionais do inconsciente, imanentes ao homem, independentemente da especificidade social, cultural ou histórica (sendo a repressão que a realidade exerce sobre as tensões e desejos provocados pelos instintos do inconsciente e da fantasia que proporcionam à mente a criação de cultura) uma das possíveis entradas do capitalismo (pela objetivação de símbolos das diversidades culturais em mercadorias para a satisfação de desejos) nas localidades (onde se reproduz sua estrutura), identifico na propaganda um instrumento pertinente para a verificação de tais questões. Pois é essa a comunicação que maneja a alteridade como demanda de mercado, para que esta deseje os seus próprios símbolos na forma das mercadorias ofertadas pelas corporações. Para a alteridade ser (na nova superestrutura) "consumidora" de seus próprios símbolos (pelos quais a realidade reprimiu os instintos do inconsciente), acaba obrigada a se transformar (na nova estrutura pós encontro com o capitalismo) em um novo proletariado.

Parto do conceito de fetiche da mercadoria (relações sociais mediadas pela troca de coisas) e sua natureza psicanalítica (a objetificação de projeções na realidade externa dos estímulos sublimados que satisfazem desejos na forma de símbolos construídos pela consciência moral coletiva) para analisar os instrumentos da propaganda na sua função de induzir o comportamento de consumo no público impactado pelas suas mensagens. O capitalismo desloca o mecanismo freudiano do "princípio de realidade" (objetos criados 
pelas estruturas locais para a sublimação de desejos) para as suas condições materiais da luta de classes entre burguesia e proletariado. Assim, tais objetos locais flutuam para as aparências do fetiche da mercadoria, que para as primeiras sociedades capitalistas (nas éticas do trabalho e do consumo de Ortiz à indústria cultural de Adorno) Marcuse define ser a construção de um "princípio de desempenho" (sublimação de desejos pelo trabalho e consumo fetichizado por baixo do conteúdo simbólico precedente pela forma aparente de tais objetos culturais "típicos" das localidades) $)^{3}$.

De que forma a propaganda desloca a sublimação dos desejos, pelos símbolos da consciência moral da alteridade precedente, para à diversidade de criações simbólicas da consciência moral resultante da ética do trabalho, da ética do consumo e do princípio de desempenho no encontro entre as condições materiais do capitalismo e as localidades do globo? De que maneira as propagandas vendem os objetos da diversidade sociocultural, que nasceu em localidades num contexto histórico distinto do capitalismo e que morreu pelas condições materiais da luta de classes entre a burguesia e o proletariado no contato da globalização, e que mesmo morta, está disponível na forma mercadoria para as novas sociedades proletarizadas?

As mais diversas condições materiais e temporalidades históricas, pelas quais, as estruturas de relações da diversidade sociocultural das localidades espalhadas por todo o globo foram criadas, morreram com a imposição das condições materiais do capitalismo (da Revolução Industrial

\footnotetext{
${ }^{3}$ A mercadoria é forma elementar da riqueza capitalista. Ela tem a propriedade de satisfazer as necessidades humanas, sejam do estômago ou da fantasia, seja como meio de subsistência ou de produção. Assim, podem ser mercadorias: o sanduíche, as condições de saúde, o show de rock... Por ser útil, diz-se que tem um valor de uso que se realiza no consumo. Coisas úteis podem não ser mercadorias, desde que não sejam produtos do trabalho e não se destinem à troca. A divisão do trabalho é condição para a produção de mercadorias, além de ser uma exigência do processo de aumento das necessidades, gerado pelo desenvolvimento das forças produtivas sociais. (QUINTANEIRO et al., 1996: 85-86)
} 
à colonização e o imperialismo) que passou a produzir os seus símbolos na forma mercadoria. Portanto, a mercadoria nada mais é do que um cadáver das condições materiais particulares que cada coletividade criava para satisfazer as suas necessidades e desejos, que é "perfumado" e "mantido sorridente" pela propaganda para persuadir os indivíduos a se sujeitarem a sua proletarização como condição sine qua non de acesso deste mesmo cadáver pelo consumo. Não obstante, o objetivo da proposta que trago com o estudo de caso desta pesquisa, pela análise destas três peças de propaganda premiadas por Cannes, é entender como a propaganda oferece com a promessa do canto de sereia (disfarçado de canto de galo), o cadáver perfumado e sorridente da diversidade sociocultural local precedente aos encontros com o capitalismo na forma mercadoria ${ }^{4}$.

Palavras Chave: Propaganda, consumo, globalização, fetiche da mercadoria, diversidade sociocultural

\section{Referências}

ADORNO, Theodor W. e HORKHEIMER, Max. Dialética do Esclarecimento. Rio de Janeiro, RJ: Jorge Zahar. 2006.

CHILDS, Harwod L. Relações públicas, propaganda e opinião pública. FGV, Rio de Janeiro. 1967.

ECO, Umberto. Apocalípticos e Integrados. São Paulo, SP: Editora Perspectiva, $7^{\text {a }}$ edição. 2011.

E Muniz. Publicidade e propaganda origens históricas. Caderno Universitário, 2004 eloamuniz.com.br

GIDDENS, A. As Consequências da Modernidade. São Paulo, SP: Editora da UNESP, $2^{a}$ edição. 1991.

\footnotetext{
${ }^{4}$ A publicidade é um cadáver perfumado. Sempre se diz a respeito dos defuntos: "Ele está bem-conservado, parece até que sorri". O mesmo vale para a publicidade. Acha-se morta, mas continua sorrindo. (TOSCANI, 2009, p.40)
} 
KOTLER, Philip e KELLER, Kevin Lane. Administração de Marketing. São Paulo, SP: Pearson Prentice Hall, 12a edição. 2006.

MARCUSE, Herbert. Eros e Civilização. Rio de Janeiro, RJ: Editora LTC, $8^{\mathrm{a}}$ edição. 1955.

MARTINS, José. A natureza emocional da Marca: como encontrar a imagem que fortalece sua marca. São Paulo, SP: Negócio. 1999.

MARX, Karl e ENGELS, Friedrich. A Ideologia Alemã. São Paulo, SP: Moraes. 1987.

MORIN, Edgar. Cultura de Massas no Século XX. Rio de Janeiro, RJ: Editora Forense, $9^{a}$ edição. 2002.

ORTIZ, Renato. In: Mundialização e Cultura. Uma Cultura Internacional Popular. Brasília, DF: Editora Brasiliense. 2007.

PEREZ, Clotilde. Signos da marca: expressividade e sensorialidade. São Paulo, SP: Pioneira Thomson Learning. 2004.

QUINTANEIRO, Tania et al. Um Toque de Clássicos: Durkheim, Marx, Weber. Belo Horizonte, MG: Editora UFMG. 1996.

ROCHA, Everardo. A sociedade do sonho: comunicação, cultura e consumo. Rio de Janeiro, RJ: Mauad, $3^{\text {a }}$ edição. 1995.

SAHLINS, Marshall. In: Cultura na Prática. Cosmologias do Capitalismo. Rio de Janeiro, RJ: Editora UFRJ. 2004.

SAMPAIO, Rafael. Marcas de A à Z: Como construir e manter marcas de sucesso. Rio de Janeiro, RJ: Campus, 2002.

SANT'ANNA, Armando. Propaganda: teoria, técnica, prática. $7^{\mathrm{a}}$ ed. São Paulo, SP: Pioneira. 2001.

TOSCANI, Oliviero. A Publicidade é um Cadáver que Sorri. Rio de Janeiro, RJ: Editora Ediouro, $6^{\text {a }}$ edição. 2009. 